\title{
ANALISIS PEMASARAN SAPI POTONG
}

\author{
(Analysis of Marketing in Beef Cattle) \\ Nurafni Lasaharu1), Nibras K. Laya ${ }^{2)}$, Yuriko Boekoesoe ${ }^{* 3 \text { ) }}$ \\ ${ }^{1}$ Alumni Jurusan Peternakan Fakultas Pertanian Universitas Negeri Gorontalo \\ 2Jurusan Peternakan Fakultas Pertanian Universitas Negeri Gorontalo \\ 3Jurusan Agribisnis, Fakultas Pertanian Universitas Negeri Gorontalo
}

*Coresponding Author: Email: yurikoboekoesoe@yahoo.co.id

\begin{abstract}
The purpose of this study was to determine the marketing analysis of beef cattle in Taluditi Regency, Pohuwato Regency. Gorontalo. The research method uses the survey method. The data used in this study are primary data with data collection techniques conducted through observation, interviews, and documentation. Sampling is determined through stratification of Random Sampling, where the sample is based on the largest population. The number of samples produced was 72 respondents. Data were analyzed descriptively. The observed variables are marketing channels, marketing margins and marketing efficiency. The findings of this study are two beef cattle marketing channels in Taluditi District, Pohuwato Regency, namely: Channel I (Farmers - Collector Traders Consumers), and Channel II are (Breeders - Collector Traders - Retailers Traders - Consumers). The average marketing margin in each marketing institution is Rp. 100,000 - Rp. 500,000. The level of marketing efficiency in each marketing institution is $0.26-3.1$
\end{abstract}

Keywords: Beef Cattle, Merketing, marketing institution

\begin{abstract}
ABSTRAK
Penelitian ini bertujuan untuk mengetahui saluran pemasaran, marjin pemasaran dan tingkat efisiensi pemasaran sapi potong di Kecamatan Taluditi, Kabupaten Pohuwato. Metode penelitian menggunakan metode survei. Data yang digunakan dalam penelitian ini adalah data primer dengan teknik pengumpulan data dilakukan melalui observasi, wawancara, dan dokumentasi. Selain itu, pengambilan sampel dilakukan melalui Stratified Random Sampling, dimana populasi dibagi menjadi berbagai tingkatan, yaitu memilih desa dengan populasi tinggi. Jumlah sampel sebanyak 72 responden. Variabel pengamatan adalah: Saluran pemasaran, Margin pemasaran dan Efisiensi Pemasaran. Temuan penelitian mengungkapkan bahwa saluran pemasaran sapi potong di Kecamatan Taluditi, Kecamatan Pohuwato, terdiri dari dua saluran, yaitu: Saluran I (Peternak Pedagang Pengumpul - Konsumen), dan Saluran II adalah (Peternak - Pedagang Kolektor - Pedagang Pengecer - Konsumen ). Nilai margin pemasaran di tiap lembaga pemasaran yaitu sebesar Rp.100,000- Rp.500,000., dengan nilai efisiensi 0.26-3.1 disetiap lembaga pemasaran
\end{abstract}

Kata kunci: Lembaga pemasaran, Pemasaran, Sapi potong 


\section{PENDAHULUAN}

Sub-Sektor peternakan di Indonesia terus berkembang sehingga memiiki prospek yang baik. Perkembangan ini didukung dengan semakin meningkatnya jumah penduduk dan taraf hidup masyarakat, sehingga menimbulkan kesadaran pentingnya mengkonsumsi protein hewani. Hal ini menyebabkan perlunya peningkatan ketersediaan bahan makanan dari hewani. Pemenuhan kebutuhan ini dapat diproduksi dari sapi potong.

Pemasaran merupakan proses lanjutan dari proses produksi sehingga pemasaran mempunyai peranan penting bagi usaha peternakan. Pemasaran adalah proses kegiatan perpindahan produk dari produsen ke konsumen. Pemasaran juga adalah sarana untuk menyampaikan produk peternakan ke konsumen. Setiap kegiatan pemasaran sapi potong akan melibatkan berbagai lembaga pemasaran. Saluran pemasaran sapi potong yang ditempuh oleh peternak yaitu : 1) Peternak memasarkan kepada konsumen akhir. 2) peternak memasarkan ternak kepada pedagang pengumpul, pengecer, pedagang besar, pedagang antar pulau atau bahkan kepada pengusaha pemotong seperti penjual daging kiloan.

Menurut Daroini, (2013) Proses menjual sapi potong, peternak memilih pembeli yang potensial, biasanya peternak mampu memutus peran belantik (makelar) sapi saat proses penjulan, menerima pembayaran dengan uang tunai tanpa menunggu dalam beberapa hari. Diawali penentuan harga sapi, peternak menerima harga sapi yang tidak ditimbang, hanya berdasarkan penaksiran bobot badan dengan cara melihat tampilan fisik sapi. Dengan menjual sapi peternak dapat memenuhi kebutuhan, biayai pendidikan anak.

Pemasaran sapi potong oleh peternak yang ada di Kecamatan Taluditi cukup tinggi, hal ini terlihat dari sapi potong yang cukup banyak tersedia dengan harga terjangkau. Untuk menciptakan pemasaran sapi potong yaitu peternak menggunakan saluran pemasaran sapi yang dilalui pedagang pemotong sampai ke tangan konsumen itu sendiri. Ada juga beberapa pedagang ternak sapi potong di Taluditi seperti blantik yaitu bertemu langsung dengan peternak melakukan transaksi secara tunai maupun kontrak pembelian dan pedagang pengumpul yaitu pedagang yang membeli ternak sapi dari blantik dengan harga yang relatif kecil.

Berdasarkan data Badan Pusat Statistik (BPS) Kabupaten Pohuwato pada Tahun 2018 total jumlah ternak sapi potong di Kabupaten Pohuwato yaitu 32,057 ekor.

Kecamatan Taluditi merupakan salah satu Kecamatan yang terdapat di Kabupaten Pohuwato memiliki jumlah populasi ternak sapi potong sebanyak 2.718 ekor ternak, sehingga daerah ini memiliki potensi untuk pengembangan budidaya sapi potong. Permasalahan yang terjadi dalam budidaya Ternak sapi adalah umumnya masih bersifat tradisional, sehingga produktifitas dari ternak lambat. Banyaknya betina bunting yang di perjual belikan sehingga 
regenerasi ternak terhambat, masalah lain juga adalah Inseminasi buatan yang tidak maksimal dalam pelaksanaannya

Ketersediaan ternak sapi ini menjadi peluang dalam pemasaran ternak, namun permasalahan yang terjadi adalah tingginya kebutuhan akan daging sapi namun produksi sapi yang belum memenuhi swasembada. Kondisi ini merupakan peluang dalam pemasaran.

Pemasaran yang terjadi di tingkat tani-ternak masih memiliki proses yang panjang. Perpindahan ternak sapi dari tani-ternak harus melalui lembaga yang berhubungan langsung atau tidak langsung yang terkait dalam kegiatan pemasaran.

Menurut Suarda, (2009); Sumantri (2013) Saluran pemasaran ternak di sapi ada 3 saluran. semakin panjang saluran pemasaran semakin besar margin pemasaran, sedangkan Ali (2014) terdapat tiga saluran pemasaran ternak sapi yaitu saluran langsung (I), saluran tidak langsung (II) dan saluran tidak langsung (III). Biaya pemasaran dan harga ditingkat peternak adalah faktor-faktor yang mempengaruhi margin pemasaran secara nyata (Koesmara, dkk, 2015)

Analisis pemasaran sapi potong ini penting dikaji sebagai upaya terinformasinya saluran dan distribusi pemasaran yang terjadi, seberapa besar margin yang dihasilkan dalam sisitim pemasaran dan apakah efisien proses pemasaran sapi potong yang terjadi ditingkat lembaga terkait. Tujuan pemnelitian ini untuk mengetahui analisis pemasaran sapi potong, yang difokuskan saluran distribusi, margin pemasaran dan efisien pemasaran sapi potong.

\section{METODE PENELITIAN}

Kecamatan Taluditi Kabupaten Pohuwato adalah tempat pelaksanaan penelitian ini, yang dilaksanakan pada bulan Juli-Agustus tahun 2019. Populasi peternak sebanyak 694 peternak, dengan jumlah ternak sapi sebanyak 1846 ekor (Kantor desa Kecamatan Taluditi, 2018). Teknik sampling yang digunakan adalah Stratified Random Sampling.

Teknik penentuan jumlah sampel dilakukan dengan menggunakan rumus Slovin. Instrument penelitian yang digunakan adalah observasi dan kuesioner yang diarahkan kepada peternak dan lembaga-lembaga pemasaran ternak sapi yang ada di kecamatan Taluditi. Analisis data dalam penelitian ini adalah analisis saluran pemasaran, analisis margin pemasaran dan analisis efisiensi saluran pemasaran. Analisis pemasaran digunakan rumus yang disarankan Singaribuan (1995) menggunakan :

1. analisis margin pemasaran:

$$
M p s=H s-H l-1
$$

Keterangan:

Mps : Margin pemsaran ternak sapi potong oleh lembaga yang lebih akhir

Hs: Harga jual ternak sapi yang diterima oleh lembaga pemsaran yang lebih akhir

Hl-1 : Harga jual ternak sapi yang diterima oleh lembaga sebelumnya 


\section{Analisis Keuntungan}

$$
\text { Lps }=M p s-B p-B t
$$

Keterangan:

Lps: Keuntungan penjualan ternak sapi pada setiap kelembagaan pemasaran

Mps :Margin pemasaran ternak sapi potong pada setiap kelembagaan

Bp : Biaya pemasaran ternak sapi potong pada setiap kelembagaan pemasaran

Bt : Biaya transaksi (biaya negosiasi dan lainnya) pada setiap kelembagaan

Analisis efisiensi pemasaran
$\mathrm{EP}=\frac{\text { Biaya Pemasaran }}{\text { Nilai Produk yang Di pasarkan }} \times 100 \%$

Ep : Efisiensi Pemasaran ternak sapi potong

BP : Biaya Pemasaran

NPD : Nilai Produk yang dipasarkan

\section{HASIL DAN PEMBAHASAN Karakteristik Responden}

\section{Umur}

Menurut (Febriana,2008) bahwa umur produktif 16-65 tahun sedangkan yang belum produktif 0-15 tahun dan yang tidak produktif $>65$ tahun. Karakteristik responden dengan presentase jumlah peternak berdasarkan tingkat umur dapat dilihat padaTabel 1 .

Tabel 1. Karakteristik peternak sapi potong berdasarkan umur di Kecamatan Taluditi Kabupaten Pohuwato

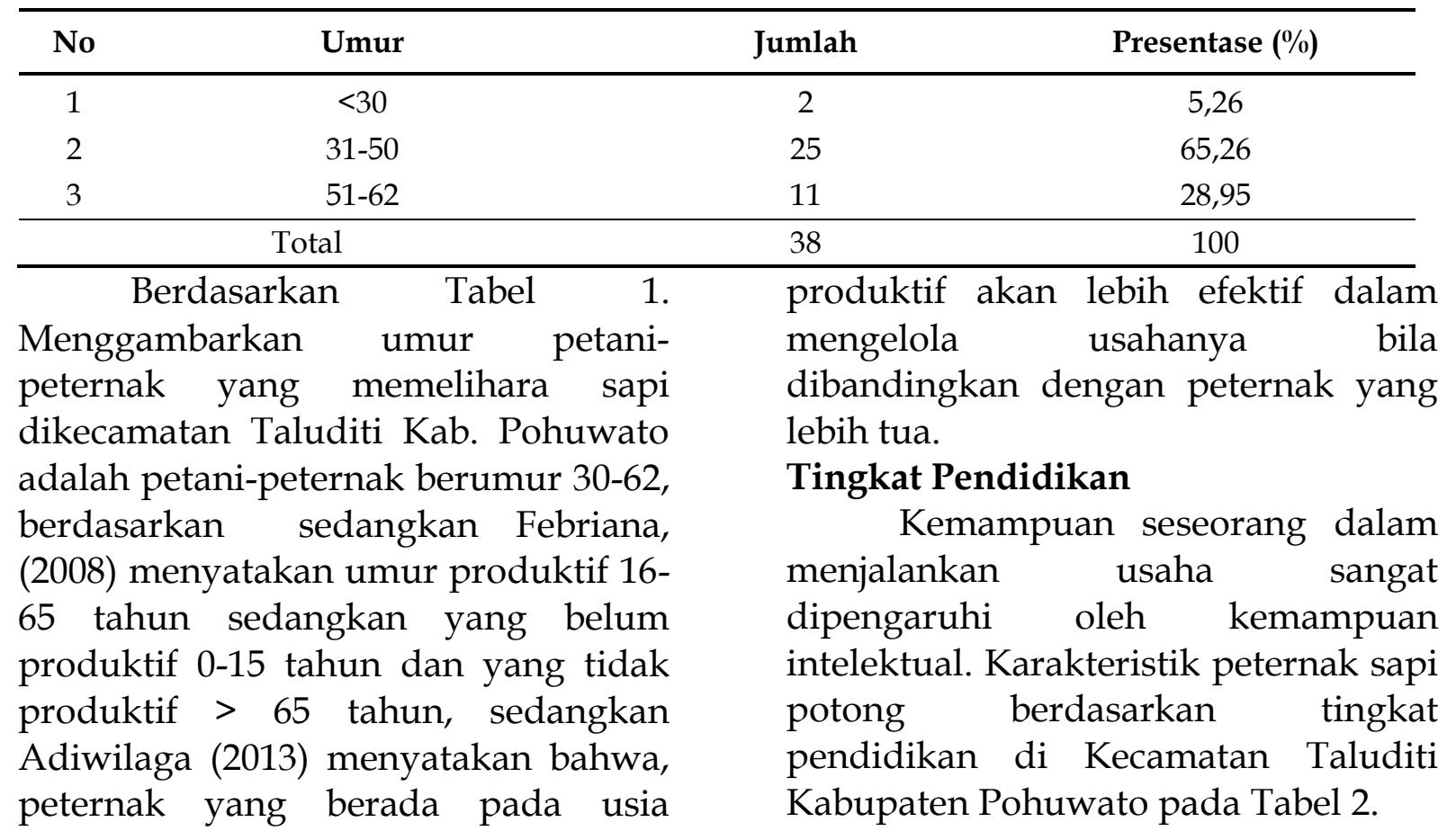


Tabel 2. Karakteristik peternak sapipotong berdasarkan pendidikan di Kecamatan Taluditi Kabupaten Pohuwato

\begin{tabular}{cccc}
\hline No & Tingkat Pendidikan & Jumlah & Presentase (\%) \\
\hline 1 & SD & 21 & 55,26 \\
2 & SLTP & 17 & 44,74 \\
3 & SLTA & 0 & 0,00 \\
\hline & Total & 38 & 100 \\
\hline
\end{tabular}

Berdasarkan tabel 2, Tingkat pendidikan tertinggi adalah tingkatan SD jumlah 21 responden dengan presentase 55,26 \%, sedangkan terendah adalah tingkatan kelompok umur responden terkecil adalah SLTP jumlah 17 responden dengan presentase $44,74 \%$, responden yang bersedia untuk diteliti tidak ada yang untuk tingkatan SLTA.Hal ini berpengaruh buruk terhadap mengelola usaha yang dijalankan terutama sikap terhadap inovasi usaha dimasa yang akan datang.

\section{Tanggungan Keluarga}

Karakteristik peternak sapi potong berdasarkan tanggungan keluarga di Kecamatan Taluditi Kabupaten Pohuwato di sajikan pada tabel 3

Tabel 3. Karakteristik peternak sapi potong berdasarkan tanggungan keluarga di Kecamatan Taluditi Kabupaten Pohuwato

\begin{tabular}{cccc}
\hline No & Tanggungan Keluarga & Jumlah & Presentase (\%) \\
\hline 1 & $<4$ Orang & 11 & 28,95 \\
2 & 4-6 Orang & 27 & 71,05 \\
3 & $>$ 6 Orang & 0 & 0,00 \\
\hline & Total & 38 & 100 \\
\hline
\end{tabular}

Berdasarkan Tabel 3, Tanggungan Keluarga yang tertinggi adalah 4-6 orang dengan jumlah 27 responden meliki presentase $71,05 \%$, sedangkan yang terendah adalah $<4$ orang dengan jumlah 11 responden memiliki presentase 28,95\%. Keadaan ini akan mempengaruhi ketersediaan tenaga kerja keluarga. (Winarso (2013) menyatakan bahwa semakin banyak jumlah anggota keluarga merupakan beban disatu sisi, akan tetapi bila dilihat dari disisi lain merupakan sumber tenaga kerja.

\section{Pengalaman Beternak}

Karakteristik peternak sapi potong berdasarkan pengalaman beternak di Kecamatan Taluditi Kabupaten Pohuwato seperti pada tabel 4. 
Tabel 4. Karakteristik peternak sapi potong berdasarkan pengalaman beternak di Kecamatan Taluditi Kabupaten Pohuwato

\begin{tabular}{cccc}
\hline No & Pengalaman Beternak & Jumlah & Presentase (\%) \\
\hline 1 & $<5$ Tahun & 7 & 18,42 \\
2 & $5-10$ Tahun & 25 & 68,42 \\
3 & $>$ 10 Tahun & 5 & 13,16 \\
\hline & Total & 38 & 100 \\
\hline
\end{tabular}

Berdasarkan pengalaman peternak dalam memelihara ternak sapi di kecamatan taluditi yakni 5-10 tahun, Pengalaman peternak menjadikan seorang peternak sapi lebih paham teknis pemeliharaan tentang ternak yang dipelihara dan merupakan motivasi dalam pengembagan usahanya serta pengambilan keputusan dalam meemasarakan hasil ternak. Soeharjo dan Patong (2010), mengatakan bahwa umur dan pengalaman beternak akan mempengaruhi kemampuan berusaha, peternak mempunyai pengalaman yang lebih banyak akan lebih berhatihati dalam bertindak karena adanya pengalaman pahit yang pernah dialam, sedangkan Sulistyati M., dkk (2013) lama beternak adalah kondisi seorang pertenak mengelola usaha ternaknya, sehingga memiliki pengalaman tentang ternak yang Tabel 5. Jumlah Ternak yang Dipelihara oleh Masing-masing Peternak

\begin{tabular}{cccc}
\hline No & Kepemilikanternak & Jumlah & Presentase (\%) \\
\hline 1 & $4-6$ ekor & 26 & 68.42 \\
\hline 2 & 6-8 ekor & 10 & 26.32 \\
3 & 8-10 ekor & 2 & 5.26 \\
4 & $>10$ ekor & 0 & 0 \\
\hline & Jumlah & 38 & 100 \\
\hline
\end{tabular}

Tingkat kepemilikan peternak terhadap ternak sapi di Kec. Taluditi Kab. Pohuwato adalah 4-10 ekor, banyaknya populasi ternak yang dimiliki oleh peternak sangat menentukan perputaran usaha ternak dipelihara dan cepat tanggap dalam penetapan kondisi usahanya.

\section{Jumlah Ternak yang di Pelihara}

Jumlah kepemilikan ternak akan dipengaruhi besar kecilnya pendapatan yang di jadikan salah satu indicator ekonomi peternak. Hasil penelitian jumlah yang dipelihara oleh masing-masing peternak sapip otong di Kecamatan Taluditi Kabupaten Pohuwato seperti pada Tabel 5.

Tingkat kepemilikan peternak terhadap ternak sapi di Kec. Taluditi Kab. Pohuwato adalah 4-10 ekor, banyaknya populasi ternak yang dimiliki oleh peternak sangat menentukan perputaran usaha ternak yang dilakukannya, hal ini dapat berpengaruh langsung terhadap jumlah pendapatan peternak. 
banyak ternak yang di pelihara dapat meningkatkan pendapatan peternak (Harry, R. K., 2014).

\section{Karateristik Lembaga Pemasaran}

Untuk mengetahui karakteristik responden pedagang pengumpul dan pedagang pengecer sapi potong dari segi umur, tingkat pendidikan dapat dilihat padaTabel 6

Tabel 6. Karakteristik pedagang pengumpul dan pedagang pengecer sapi potong berdasarkan umur peternak di Kecamatan Taluditi Kabupaten Pohuwato

\begin{tabular}{cccc}
\hline No & Umur (tahun) & JumlahResponden Orang & Presentase (\%) \\
\hline 1 & $<30$ & 2 & 6 \\
2 & $30-50$ & 21 & 62 \\
3 & $>50$ & 11 & 32 \\
\hline & Total & 34 & 100 \\
\hline
\end{tabular}

Berdasarkan Tabel 6, Dari segi umur pedagang pengumpul dan pedagang pengecer kelompok umur yang terbebesar adalah kelompok umur 30-50 tahun dengan jumlah 21 responden dengan presentase
$62 \%$, sedangkan kelompok umur responden terkecil adalah kelompok umur $<30$ tahun sebanyak 2 responden dengan presentase $6 \%$. Digolongkan pada usia produktif lebih dari 50 tahun.

Tabel 7. Karakteristik responden pedagang pengumpul dan pedagang pengecer menurut tingkat pendidikan di Kecamatan Taluditi Kabupaten Pohuwato

\begin{tabular}{cccc}
\hline No & Tingkat pendidikan & JumlahResponden Orang & Presentase (\%) \\
\hline 1 & SD & 21 & 61,76 \\
2 & SLTP & 12 & 35 \\
3 & SLTA & 1 & 2,94 \\
\hline & Total & 34 & 100 \\
\hline
\end{tabular}

Berdasarkan tabel 7, Tingkat pendidikan tertinggi adalah tingkatan SD jumlah 21 responden dengan presentase $61,76 \%$, sedangkan terendah adalah tingkatan kelompok umur responden terkecil adalah SLTA jumlah 1 responden dengan presentase $2,94 \%$.

\section{Saluran Pemasaran}

Dari hasil survei menunjukan bahwa aktifitas pemasaran ternak sapi potong yang ada di Kecamatan Taluditi terdapat 2 jenis saluran pemasaran. 


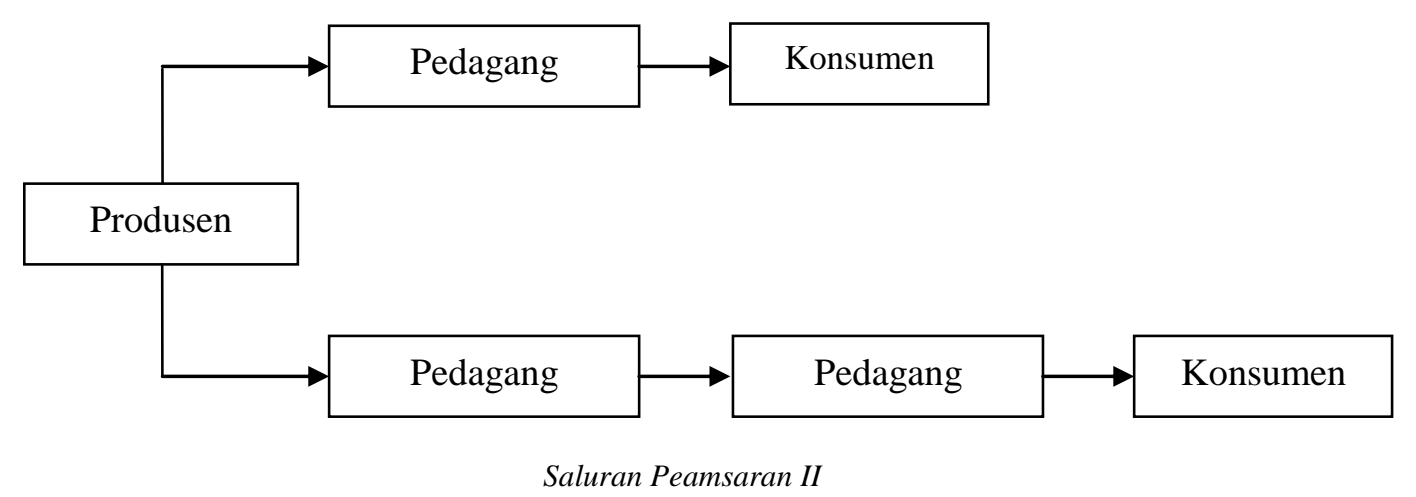

Gambar 1 : Saluran Pemasaran Sapi Potong di Kecamatan Taluditi Kabupaten Pohuwato

Gambar 1 menunjukkan saluran pemasaran ternak sapi potong yang ada di Kecamatan Taluditi Kabupaten Pohuwato terdapat 2 jenis saluran pemasaran

\section{Saluran Pemasaran Pertama}

Bentuk saluran pemasaran pertama, peternak menjual sapinya kepada pedagang pengumpul, hal ini dikarenakan peternak mengambil langkah mudah untuk menjual sapinya kepada pedagang pengumpul karenamereka lebih mepercayakannya kepada pedagang pengumpul, adanya ketidaktahuan peternak mengenai pemasaran sapi potong dan harga sapi potong di pasar hewan dapat menjadi salah satu sebab peternak menjual langsung kepada pedagang pengumpul. Pada saluran pertama ini pedagang pengumpul menjual sapi potong kepada konsumen di pasar hewan Taluditi. Pemasaran di lembaga awal ini terlihat sangat menguntungkan, dimana peternak langsung menjual kepada pedagang atau konsumen langsung yang membutuhkan ternak sapi.

Harga saluran pemasaran I pada tingkat peternak yaitu sebesar $79,40 \%$, bagian harga pada tingkat mugee sebesar $7,27 \%$ dan harga pada tingkat pedagang daging yang sebesar 13,33\%, (Koesmara,2015)

2. Saluran Pemasaran ke-dua:

Bentuk saluran kedua,peternak menjual sapi kepada pedagang pengumpul kemudian pedagang pengumpul menjual kembali kepada kepada pedagang pengecer. kemudian pedagang pengecer mejual langsung kepada konsumen. pada saluran kedua pedagang pengumpul mudah dalam pemasaran sapi potong karena mendapat bantuan pemasaran melalui pedagang pengecer.

Hasil penelitian ini berbeda dengan hasil penelitiaan Ali, (2014) menyatakan Terdapat tiga bentuk saluran pemasaran ternak sapi di Kabupaten Gorontalo yaitu saluran langsung I, saluran tidak langsung II dan saluran tidak langsung III., 
sedangkan Heryadi, (2010) menyatakan saluran pemasaran sapi potong di pulau Madura adalah panjang, dan kompleks. Lembaga tataniaga yang telibat sangat banyak tetapi tidak ada satupun lembaga tataniaga yang bertindak sebagai pengimbang.

Saluran pemasaran II harga di tingkat peternak sebesar $81,79 \%$ dan pada tingkat pedagang daging sebesar 18,21\%. (Koesmara,2015)

\section{Margin Pemasaran}

Margin merupakan perbedaan harga atau selisi harga yang dibayar konsumen akhir dengan harga yang diterima oleh peternak (Simmanora, 2010). Dalam hal ini margin pemasaran pedagang pengumpul adalah perbedaan harga yang dibayarkan kepada peternak dengan harga jual kepada pedagang pengecer dan konsumen dalam saluran pemasaran dengan komoditi yang sama (Ali, 2014).

Tabel 8. Margin Pemasaran Pada Saluran I Sapi Potong di Kecamatan Taluditi Kabupaten Pohuwato

\begin{tabular}{|c|c|c|c|}
\hline \multirow{2}{*}{ No } & \multirow{2}{*}{ Lembaga Pemasaran } & \multicolumn{2}{|c|}{ Saluran I } \\
\hline & & Nilai Rata-Rata (Rp/Ekor) & Presentase (\%) \\
\hline \multirow{6}{*}{1} & Peternak & & \\
\hline & a. HargaJual & $9,500,000$ & \\
\hline & b. BiayaPemasaran & & \\
\hline & - BiayaTenagaKerja & 38,816 & 13 \\
\hline & - BiayaTransportasi & 222,237 & 74 \\
\hline & - $\quad$ BiayaRestribusi & 38,816 & 13 \\
\hline \multirow{7}{*}{2} & PedagangPengumpul & & \\
\hline & a. HargaBeli & $9,500,000$ & \\
\hline & b. BiayaPemasaran & & \\
\hline & - BiayaTenagaKerja & 88,095 & 12 \\
\hline & - BiayaTransportasi & 528,571 & 72 \\
\hline & - BiayaRestribusi & 114,286 & 16 \\
\hline & c. HargaJual & $9,600,000$ & \\
\hline \multirow[t]{2}{*}{3} & $\begin{array}{l}\text { KonsumenAkhir } \\
\text { HargaBeli }\end{array}$ & $9,600,000$ & 100 \\
\hline & Margin Pemasaran & 100,000 & \\
\hline
\end{tabular}

Berdasarkan Tabel 8, Saluran pemasaran I di lembaga pemasaran yang meyalurkan sapi potong terdiri dari peternak, pedagang pengumpul dan konsumen akhir. Total margin keseluruhan yaitu Rp.100,000, dimana total biaya pemasaran keseluruhan sebesar Rp.1,030,821/ekor. Dengan perhitungan biaya tenaga kerja $\mathrm{Rp}$. 88,095/orang, biaya transportasi Rp. 528,571/ekor, dan biaya restribusi Rp. 114.286/bln.
Pada saluran pemasaran II memiliki margin lebih banyak dengan jumlah Rp. 500,000/ekor karena hanya melalui lembaga pemasaran yaitu lembaga pemasaran yang terdiri dari peternak, pedagang pengumpul, pedangang pengecer dan konsumen.

Menurut Sumantri (2013) Saluran pemasaran ternak di Kabupaten Ogan Komering Ilir ada 3 saluran. Saluran pemasaran I mempunyai margin pemasaran 
terbesar yaitu Rp2.562.835,-/ekor, hal ini membuktikan bahwa semakin panjang saluran pemasaran semakin besar margin pemasaran.

Harga saluran pemasaran I pada tingkat peternak yaitu sebesar $79,40 \%$, bagian harga pada tingkat mugee sebesar $7,27 \%$ dan harga pada tingkat pedagang daging yang sebesar $13,33 \%$, sedangkan pada saluran pemasaran II harga di tingkat peternak sebesar $81,79 \%$ dan pada tingkat pedagang daging sebesar 18,21\%. (Koesmara,2015)

Besaran marjin tataniaga ditentukan oleh besar kecilnya biaya yang dikeluarkan dan resiko yang ditanggung oleh lembaga Tataniaga. Share biaya dan share keuntungan cukup merata, kecuali share biaya untuk pedagang pengumpul kecil, sehingga pemasaran sapi potong di pulau Madura dapat dikatakan efisien (Heryadi, 2010)

Tabel 9. Margin Pemasaran Pada Saluran II Sapi Potong di Kecamatan Taluditi Kabupaten Pohuwato

\begin{tabular}{|c|c|c|c|}
\hline \multirow{2}{*}{ No } & \multirow{2}{*}{ LembagaPemasaran } & \multicolumn{2}{|c|}{ Saluran II } \\
\hline & & Nilai Rata-Rata (Rp/Ekor) & Presentase (\%) \\
\hline \multirow{6}{*}{1} & Peternak & & \\
\hline & a. HargaJual & $9,500,000$ & \\
\hline & b. BiayaPemasaran & & \\
\hline & - BiayaTenagaKerja & 38,816 & 13 \\
\hline & - BiayaTransportasi & 222,237 & 74 \\
\hline & - Biaya Restribusi desa & 38,816 & 13 \\
\hline \multirow{7}{*}{2} & PedagangPengumpul & & \\
\hline & a. HargaBeli & $9,500,000$ & \\
\hline & b. BiayaPemasaran & & \\
\hline & - BiayaTenagaKerja & 88,095 & 12 \\
\hline & - BiayaTransportasi & 528,571 & 72 \\
\hline & - $\quad$ BiayaRestribusi & 114,286 & 16 \\
\hline & c. HargaJual & $9,600,000$ & \\
\hline \multirow{7}{*}{3} & PedagangPengecer & & \\
\hline & a. HargaBeli & $9,600,000$ & \\
\hline & b. BiayaPemasaran & & \\
\hline & - Biaya Tenaga Kerja & 50,000 & 13 \\
\hline & - $\quad$ BiayaTransportasi & 288,462 & 75 \\
\hline & - BiayaRestribusi & 48,077 & 12 \\
\hline & c. HargaJual & $10,000,000$ & \\
\hline \multirow[t]{2}{*}{4} & $\begin{array}{l}\text { KonsumenAkhir } \\
\text { HargaBeli }\end{array}$ & $10,000,000$ & 100 \\
\hline & Margin Pemasaran & 500,000 & \\
\hline
\end{tabular}

Berdasarkan Tabel 9, menunjukan bahwa, saluran II lembaga pemasaran yang menyalurkan sapi potong terdiri dari peternak, pedagang pengumpul, pedagang pengecer dan konsumen akhir. Total margin keseluruhan yaitu Rp.500,000 yang dimana total biaya pemasaran untuk pedagang pengecer Rp.1,330,385/ekor.

Dengan perhitungan tenaga kerja untuk pedagang pengumpul Rp.88,095/orang, biaya transportasi Rp.528,571/ekor, dan biaya distribusi Rp.114,286/bln. Sedangkan untuk pedagang pengecer perhitungan 
tenaga kerja Rp.50,000/orang, biaya transportasi Rp.288,462/ekor, dan biaya retribusi Rp.48,077/bln.

Berdasarkan margin pemasaran, peternak, pedagang pengumpul, dan pedangang pengecer terdapat perbedaan pada saluran pemasaran dipengaruhi oleh beberapa faktor diantaranya lembaga yang terlibat dan besarnya yang dikeluarkan oleh suatu lembaga pemasaran.

Menurut Indriyo (2001) bahwa, semakin panjang dan semakin banyak lembaga pemasaran yang terlibat dalam proses pemasaran akan semakin besar total margin dan laba bersih yang didapat oleh pelaku pemasaran, sebaliknya semakin pendek dan sedikit lembaga pemasaran yang terlibat dalam proses pemasaran semakin kecil total margin dan laba bersih yang didapat lembaga pemasaran, sedangkan Amalia dkk (2013) menyatakan bahwa, besar kecilnya margin pemasaran dipengaruhi oleh perubahan biaya pemasaran, keuntungan pedagang perantara, harga yang dibayar oleh konsumen akhir dan harga yang diterima oleh produsen.

\section{Efisiensi Pemasaran}

Secara umum efisiensi pemasaran adalah nisbih antara biaya pemasaran dengan nilai produk yang dinyatakan dengan persen. Efesiensi pemasaran pada setiap lembaga dapat dilihat pada Tabel 10.

1. Lembaga Pemasaran untuk peternak

Efesiensi pemasaran pada tingkat lembaga pemasaran I yaitu Harga jual ternak sapi oleh peternak kepada pedagang pengumpul sebesar
Rp. 9,500,000/ekor dan biaya pemasaran sapi potong yang dikeluarkan sebesar Rp. 299,868.42/ekor. Jadi efisiensi pemasaran ternak sapi potong yaitu : $\mathrm{EP}=3,1 \%$

2. Lembaga Pemasaran untuk Pedagang Pengumpul

Efisiensi pemasaran pada tingkat lembaga pemasaran II yaitu rata-rata harga jual ternak sapi potong oleh pedagang pengumpul sampai kepada pedagang pengecer sebesar Rp.9,600,000/ekor dan biaya pemasaran ternak sapi yang dikeluarakan dalam waktu tersebut sebesar Rp. 704,761,90. Jadi efisiensi pemasaran ternak sapi potong yaitu : $\mathrm{EP}=0,73 \%$

3. Status untuk pedagang pengecer

Efisiensi pemasaran pada tingkat saluran pemasaran III yaitu, diketahui Rata-rata nilai produk ternak sapi potong oleh pedagang pengecer sampai ke konsumen sebesar Rp.10,000,000 dan biaya pemasaran yang di keluarkan sebesar Rp. 263,846.15. Jadi efisiesi pemasaran ternak sapi potong yaitu : $\mathrm{EP}=0,26 \%$

Efisiensi pemasaran sapi potong dalam penelitian ini menunjukkan efisien hal ini ditunjukkan nilai efisiensi di lembaga pemasaran sebesar $0.23-3.1 \%$

Nilai Efisiensi dalam penelitian ini sama dengan penelitian yang dilaksanakan oleh Agusu, (2019) yakni nilai efisiensi pemasaran berkisar 0-5\%

Efisiensi pemasaran di pengaruhi oleh pola pemasaran dan faktor lain diluar model pemasaran, sedangkan margin pemasaran juga ditentukan oleh penerimaan dan 
dikurangi biaya yang dikeluarkan selama proses produksi (Dermawan R.A, dkk 2018).

Menurut Syahdani dan Hanafi, (2016) Pola pemasaran yang paling efisien adalah pola I. Hal ini disebabkan karena biaya yang dikeluarkan pada pola pemasaran I lebih kecil dan lembaga yang terlibat lebih sedikit dibandingkan dengan saluran pemasaran lainnya karena peternak menjual langsung ke konsumen

Tabel 10. Tingkat Efisiensi Pemasaran pada Setiap Lembaga Pemasaran

\begin{tabular}{lcc}
\hline \multicolumn{1}{c}{ Lembaga Pemasaran } & Tingkat Efisiensi (\%) & Keterangan \\
\hline Peternak & 3,1 & Efisien \\
PedagangPengumpul & 0,73 & Efisien \\
Pedangan Pengecer & 0,26 & Efisien \\
\hline
\end{tabular}

Jika Efisiensi Pemasaran adalah 0-5\% maka saluran pemasaran dikatakan efisien, sedangkan EP lebih besar dari 5\% maka saluran pemasaran kurang efisien. Faktor-faktor yang mempengaruhi efisiensi pemasaran adalah margin dan biaya pemasaran serta jumlah lembaga pemasaran terkait (Agusu, 2019)

\section{KESIMPULAN}

Saluran Pemasaran sapi potong yang dijumpai di Kecamatan Taluditi Kabupaten Boalemo Provinsi Gorontalo terdapat 2 saluran pemasaran yaitu: Saluran Pemasaran I adalah Peternak - Pedagang Pengumpul -Konsumen. Saluran Pemasaran II adalah: Peternak Pedagang Pengumpul - Pedagang pengecer - Konsumen. Nilai margin pemasaran di tiap lembaga pemasaran yaitu sebesar Rp.100,000- Rp.500,000., dengan nilai efisiensi 0.26-3.1 disetiap lembaga pemasaran

\section{DAFTAR PUSTAKA}

Adiwilaga, E. 2013. Analisis Saluran Pemasaran Dan Marjin Pemasaran Kelapa di Daerah Perbatasan Kalimantan Timur. Jurnal AGRIFORAR. Vol 11 (1) :1-10

Andhika R, Hasnudi, dan Ginting N., 2014. Pengaruh rantai Tata Niaga Terhadap Efisiensi Pemasaran Daging Sapi Di Kab. Karo. Jurnal Peternakan Itegratif. Vol 3 No 2 : 224-234

ALI, I. (2014). Analisis margin pemasaran ternak sapi bali di Kecamatan Pulubala Kabupaten Gorontalo. Skripsi, 1 (621409041).

Alamsyah, A. F. (2015). Analisis Saluran Dan Margin Pemasaran Sapi Potong Di Pasar Hewan Tanjungsari. Students E-Journal, 4(2). 
Amalia, A.J, D.H. Utami, A.B. Nugroho. 2013. Analisis Pemasaran Usaha Sapi potong skala Kecil dan besar pada pola Kemitraan Sinar Sarana sentosa. Malang, Fakultas Peternakan, Universitas Brawijaya

Badan Pusat Statistik. 2018. Profil Kecamatan. BPS. Pohuwato. Gorontalo

Daroini, A. (2013). Pola pemasaran sapi potong pada peternak skala kecil di Kabupaten Kediri. Jurnal Manajemen Agribisnis, 13(1), 55-62.

Dermawan, R. (2018). Analysis Feasibility of Effort Breeding Laying Hens. Jambura Journal of Animal Science, 1(1). November 2018; 24-39. PISSN 2655-4356. EISSN 26552280. Department of Animal Husbandry. Gorontalo State University

Febriana. 2008. Metode Penelitian Kuantitatif. Bandung: Alfabeta.

Heryadi, A. Y. (2010). Pola pemasaran sapi potong di pulau Madura. JSEP (Journal of Social and Agricultural Economics), 5(2), 3846.

Indriyo, G.S. 2001. Akuntansi Biaya Edisi Ketujuh. Penerbit BPFE, Yogyakarta.

Koesmara, H., Nurtini, S., \& Budisatria, I. G. S. (2015). Faktor-faktor yang mempengaruhi margin pemasaran sapi potong dan daging sapi di Kabupaten Aceh Besar. Buletin Peternakan, 39(1), 57-63.

Syahdani, A., dan Hanafi, N. D. (2016). Analisis Pendapatan Dan Efisiensi Pemasaran Usaha Sapi Potong Di Kabupaten Langkat. Jurnal Peternakan Integratif, 4(3), 222-234.

Simmanora, 2010. Manajemen Pemasaran Internasional. Jilid II. Salemba Empat, Jakarta

Soeharjo, A dan S. Patong. 2010. Potensi Agribisnis Usaha Ternak Sapi Potong dikota kendari. Jitro Vol. 1 (1) :88-98

Sulistyati M, Hermawan, dan Fitriani A. 2013. Potensi Usaha Peternakan Sapi Perah Rakyat dalam Menghadapi Pasar Global. Fakultas Peternakan. Universitas Padjadjaran. Jurnal Ilmu Ternak, Juni 2013, Vol. 13, No. 1

Suarda, A. (2009). Saluran pemasaran sapi potong di Sulawesi Selatan. Jurnal Sains dan Teknologi, 9, 113118.

Sumantri, J., Kusumastuti, T. A., \& Widiati, R. (2013). Pemasaran ternak sapi potong di Kabupaten Ogan Komering Ilir, Sumatera Selatan. Buletin Peternakan, 37(1), 49-58. 
Winarso, A. 2013. Jumlah Perusahan menurut anggota. Penerbit Rajawali. Malang 